\title{
PERMINTAAN EKSPOR SARUNG TANGAN LATEKS MALAYSIA
}

\author{
Export Demand for Malaysian Rubber Glove
}

\author{
Lina Fatayati SYARIFA
}

Balai Penelitian Sembawa, Pusat Penelitian Karet Jalan Raya Palembang - P. Balai KM 29, PO BOX 1127 Palembang 30001

Diterima tgl. 2 September 2011/Disetujui 26 Nopember 2011

\begin{abstract}
Malaysia is the leading supplier of surgical gloves, gaining about $45 \%$ of the world's market share. However, the export demand Malaysian surgical glove has fluctuated time to time. It was due to the export price, foreign income, and price of synthetic rubber. To increase the exports demand, some policies have been issued through the Third Industrial Master Plan. The aim of this study was to estimate elasticities of this product to changes in factors that significantly influenced the export demand for rubber glove. Quarterly data were used to estimate the export demand function with an error correction model. The estimation results showed that the export price elasticity of glove had significant value of -1.14 , indicating that its value was elastic. Thus, the changes of export price would give important effect to export quantity demanded. Based on foreign income elasticity, the income of glove was 0.5 and not significant statistically. This indicated that the foreign income was not an important determinant of export demand for glove. Then, the elasticity of substitute price was 0.05, indicating that the glove was inelastic against synthetic rubber.
\end{abstract}

Keywords: Surgical glove, export demand, industrial master plan

\begin{abstract}
Abstrak
Malaysia merupakan penyalur terkemuka untuk produk sarung tangan medis/bedah, dengan menguasai $45 \%$ dari permintaan dunia. Namun, permintaan ekspor untuk sarung tangan tersebut berfluktuasi dari waktu ke waktu. Hal ini antara lain disebabkan oleh perubahan faktor-faktor harga ekspor, pendapatan luar negeri, dan harga karet sintetis dunia. Untuk meningkatkan ekspornya, beberapa kebijakan telah dikeluarkan melalui Industrial Master Plan. Tujuan penelitian ini adalah untuk mengestimasi elastisitas
\end{abstract}

permintaan ekspor sarung tangan terhadap perubahan faktor-faktor yang mempengaruhi permintaan ekspornya secara signifikan. Data triwulan digunakan untuk mengestimasi fungsi permintaan ekspor dengan model ECM. Hasil estimasi menunjukkan bahwa elastisitas harga ekspor sarung tangan signifikan nilainya sebesar -1,14, menunjukkan bahwa nilainya adalah elastis. Dengan demikian, perubahan harga ekspor sarung tangan akan memberikan efek sangat penting bagi jumlah ekspor yang diminta. Berdasarkan elastisitas pendapatan luar negeri terhadap sarung tangan adalah 0,5 dan tidak signifikan secara statistik, menunjukkan bahwa pendapatan luar negeri tidak menjadi penentu penting dari permintaan ekspor sarung tangan. Kemudian, elastisitas harga substitusi nilainya sebesar 0,05, menunjukkan bahwa nilainya inelastis terhadap karet sintetis.

Katakunci: Sarung tangan bedah, permintaan ekspor, industrial master plan

\section{PENDAHULUAN}

Industri hilir karet di Malaysia memiliki peranan yang sangat penting dalam sektor manufaktur, karena memberikan kontribusi yang cukup signifikan terhadap pendapatan nasional. Pada tahun 2009, industri hilir karet memberikan kontribusi sekitar RM 10,6 Miliar, atau setara dengan US\$ 3,1 Milliar $(1,9 \%$ dari total ekspor nasional) (Lembaga Getah Malaysia, 2010). Pada tahun 2009, industri hilir karet Malaysia berjumlah lebih dari 340 produsen yang memproduksi produk-produk berbasis lateks, ban, serta produk-produk karet untuk industri dan umum (Tabel 1). Industri ini terdiri atas empat produk sub-sektor, yaitu: a) produk lateks (alat-alat medis, sarung tangan industri dan rumah tangga, benang lateks, balon, dan produk busa); b) 
produk-produk ban; c) produk karet untuk industri dan umum (conveyor belt, dock fender, suku cadang otomotif dan komponen-komponen lainnya yang meliputi sumbat pintu, lantai keramik, segel pipa, bantalan kereta api, botol air panas, bola golf, mainan dan partikel lainnya dari karet) dan d) alas kaki yang telah menjadi sumber mata pencaharian bagi lebih dari 56000 penduduk (Lembaga Getah Malaysia, 2010).

Produk lateks adalah sub-sektor terbesar dalam industri produk karet yang telah memberikan kontribusi sebesar $79 \%$ dari total nilai ekspor barang jadi karet, sebagian besar berasal dari ekspor produk sarung tangan, kondom, kateter dan benang karet. Malaysia merupakan salah satu produsen dan eksportir terkemuka di dunia untuk produk kateter, benang lateks, dan sarung tangan karet alam (Lembaga Getah Malaysia, 2010). Nilai ekspor barang jadi karet Malaysia dan kontribusinya terhadap ekspor nasional dapat dilihat pada Tabel 2.

Produk yang memberikan kontribusi terbesar terhadap pendapatan dari produk lateks adalah sarung tangan (Tabel 3). Di pasar internasional, Malaysia merupakan penyalur terbesar untuk sarung tangan medis/bedah, dengan menguasai $45 \%$ dari permintaan dunia (Malaysian Industrial Develop-ment Authority, 2008). Peningkatan pertumbuhan ekonomi dunia, telah mendorong peningkatan standar hidup dan standar kesehatan masyarakat. Hal ini memberi peluang bagi Malaysia untuk meningkatkan pertumbuhan ekspor barang jadi karet, terutama produk sarung tangan medis/bedah ke pasar internasional.

Dari tahun ke tahun ekspor produk yang terbuat dari lateks mengalami fluktuasi (Tabel 2). Fluktuasi ekspor tersebut disebab-kan beberapa faktor, antara lain harga ekspor, pendapatan dunia serta harga barang substitusi. Sejauh mana pengaruh dari berbagai variabel tersebut terhadap jumlah permintaan produk lateks perlu diketahui dengan menganalisis respons konsumen dari negara-negara pengimpor terhadap perubahan variabel-variabel tersebut. Untuk mengukur respons ini, para ahli ekonomi biasanya menggunakan fungsi permintaan ekspor. Dalam fungsi permintaan ekspor, Susanto (2002), dalam penelitiannya terhadap model permintaan ekspor menyatakan bahwa permintaan ekspor dinyatakan sebagai fungsi dari harga produk itu sendiri, harga produk substitusi dan pendapatan luar negeri.

Artikel ini bertujuan untuk menganalisis faktor-faktor yang mempengaruhi permintaan ekspor produk lateks yaitu sarung tangan lateks. Hasil analisis akan menjadi dasar dalam menentukan upayaupaya untuk meningkatkan permintaan ekspor produk tersebut.

\section{BAHAN DAN METODE}

Penelitian ini menggunakan data time series dengan menggunakan 40 observasi. Semua data time series adalah data triwulanan mulai dari tahun 1998 triwulan I sampai dengan tahun 2007 triwulan IV. Variabel-variabel untuk mengestimasi fungsi permintaan ekspor sarung tangan meliputi: kuantitas ekspor (Q), harga ekspor (P) yang merupakan nilai ekspor (FOB) dibagi dengan volume ekspor, pendapatan dunia (Y) merupakan pendapatan domestik bruto (PDB) per kapita negara-negara yang masuk dalam organisasi untuk kerjasama ekonomi dan pembangunan (OECD), dan harga substitusi (Ps) yang merupakan harga karet sintetis. Data time series triwulanan diperoleh dari Lembaga Getah Malaysia (LGM), Matrade dan Departemen Statistik Malaysia serta Organization for Economic Cooperation and Development (OECD).

Model yang dipakai dalam penelitian ini dirancang sesuai dengan tujuan penelitian dengan menggunakan model permintaan ekspor yang sama dengan yang dilakukan oleh Susanto (2002). Fungsi permintaan ekspor untuk sarung tangan adalah sebagai berikut:

$$
Q_{\mathrm{ST}}=\alpha+\beta_{1} \mathrm{P}_{\mathrm{ST}}+\beta_{2} \mathrm{Y}+\beta_{3} \mathrm{P}_{\mathrm{KS}}+\varepsilon_{\mathrm{t}} \ldots
$$

di mana:

$\mathrm{Q}_{\mathrm{ST}}$ : jumlah ekspor sarung tangan lateks,

$\mathrm{P}_{\mathrm{ST}}$ : harga ekspor sarung tangan,

$\mathrm{Y}$ : pendapatan dunia,

$\mathrm{P}_{\mathrm{KS}}$ : harga substitusi (harga karet sintetis) dan,

$\varepsilon_{\mathrm{t}} \quad$ : errorterm.

Berbagai model analisis telah diterapkan untuk mengestimasi fungsi permintaan 
Tabel 1. Profil manufaktur barang jadi karet berdasarkan jenis produk di Malaysia Table 1. Manufacture profile of Malaysian rubber products based on type of products

\begin{tabular}{|c|c|c|c|c|c|c|c|c|c|c|}
\hline \multirow{2}{*}{\multicolumn{2}{|c|}{$\begin{array}{l}\text { Jenis Produk } \\
\text { Type of Products }\end{array}$}} & \multicolumn{9}{|c|}{$\begin{array}{c}\text { Jumlah Pabrik } \\
\text { Number of Companies }\end{array}$} \\
\hline & & 2001 & 2002 & 2003 & 2004 & 2005 & 2006 & 2007 & 2008 & 2009 \\
\hline \multirow{6}{*}{$\begin{array}{l}\text { a. Produk lateks } \\
\text { (Latex productc) }\end{array}$} & $\begin{array}{l}\text { Sarung tangan } \\
\text { (glove) }\end{array}$ & 100 & 102 & 104 & 104 & 107 & 63 & 60 & 56 & 57 \\
\hline & Kondom (condom) & 5 & 12 & 12 & 12 & 14 & 14 & 13 & 12 & 13 \\
\hline & $\begin{array}{l}\text { Kateter (catheters) } \\
\text { Benang karet (latex }\end{array}$ & 6 & 6 & 7 & 7 & 7 & 8 & 7 & 7 & 7 \\
\hline & threads) & 11 & 5 & 4 & 4 & 4 & 6 & 5 & 3 & 3 \\
\hline & Lainnya (others) & 10 & 10 & 11 & 11 & 12 & 44 & 51 & 42 & 45 \\
\hline & Total & 132 & 135 & 138 & 138 & 144 & $\underline{134}$ & 136 & 120 & 125 \\
\hline \multicolumn{2}{|c|}{$\begin{array}{l}\text { b. Produk karet umum } \\
\text { General rubber goods }\end{array}$} & 125 & 124 & 131 & 135 & 136 & 152 & 155 & 151 & 154 \\
\hline Industrial rubber goods & $\begin{array}{l}\text { dustri } \\
\text { goods }\end{array}$ & 56 & 56 & 57 & 57 & 60 & 33 & 30 & 28 & 31 \\
\hline \multicolumn{2}{|l|}{$\begin{array}{l}\text { d. Alas khaki } \\
\text { Footwear }\end{array}$} & 13 & 14 & 14 & 14 & 14 & 29 & 20 & 18 & 17 \\
\hline \multirow{2}{*}{\multicolumn{2}{|c|}{$\begin{array}{l}\text { e. Ban (tyre) } \\
f . \text { Ban dalam } \\
\text { Inner tubes }\end{array}$}} & 4 & 4 & 4 & 4 & 3 & 10 & 10 & 11 & 11 \\
\hline & & - & - & - & - & - & 11 & 11 & 11 & 10 \\
\hline \multicolumn{2}{|l|}{$\begin{array}{l}\text { Total industri } \\
\text { Total industry }\end{array}$} & 330 & 333 & 344 & 348 & 357 & 369 & 362 & 339 & 348 \\
\hline
\end{tabular}

Sumber: Lembaga Getah Malaysia (LGM), 2010

Source: Malaysian Rubber Board (MRB), 2010

Tabel 2. Nilai ekspor barang jadi karet Malaysia, 1998-2009

Table 2. Export value of Malaysian rubber products, 1998-2009

\begin{tabular}{|c|c|c|c|c|c|c|c|c|}
\hline \multirow[b]{2}{*}{$\begin{array}{l}\text { Tahun } \\
\text { Year }\end{array}$} & \multicolumn{6}{|c|}{$\begin{array}{l}\text { Nilai ekspor barang jadi karet (Juta RM) } \\
\text { Export value of rubber products (Million RM) }\end{array}$} & \multicolumn{2}{|c|}{$\begin{array}{l}\text { Total Industri } \\
\text { Industry total }\end{array}$} \\
\hline & $\begin{array}{c}\text { Produk } \\
\text { ban } \\
\text { Tyres }\end{array}$ & $\begin{array}{c}\text { Ban } \\
\text { dalam } \\
\text { Inner } \\
\text { Tubes }\end{array}$ & $\begin{array}{l}\text { Alas kaki } \\
\text { Footwear }\end{array}$ & $\begin{array}{l}\text { Produk } \\
\text { lateks } \\
\text { Latex } \\
\text { products }\end{array}$ & IRGs & GRGs & $\begin{array}{l}\text { Nilai } \\
\text { ekspor } \\
\text { Export } \\
\text { values }\end{array}$ & $\begin{array}{c}\% \\
\text { Ekspor } \\
\text { nasional } \\
\text { National } \\
\text { export }\end{array}$ \\
\hline 1998 & 322 & 16 & 212 & 5.260 & 198 & 483 & 6.491 & 2,3 \\
\hline 1999 & 293 & 15 & 275 & 4.738 & 197 & 509 & 6.027 & 2,4 \\
\hline 2000 & 170 & 14 & 313 & 4.459 & 57 & 499 & 5.513 & 1,5 \\
\hline 2001 & 517 & 32 & 349 & 4.304 & 140 & 487 & 5.828 & 1,7 \\
\hline 2002 & 422 & 34 & 303 & 4.333 & 65 & 475 & 5.632 & 1,6 \\
\hline 2003 & 309 & 16 & 460 & 4.808 & 154 & 565 & 6.312 & 1,6 \\
\hline 2004 & 444 & 24 & 1,310 & 5.864 & 194 & 630 & 8.467 & 1,8 \\
\hline 2005 & 488 & 29 & 598 & 6.244 & 264 & 695 & 8.318 & 1,6 \\
\hline 2006 & 598 & 25 & 571 & 7.067 & 331 & 741 & 9.334 & 1,6 \\
\hline 2007 & 954 & 28 & 560 & 7.701 & 422 & 761 & 10.426 & 1,7 \\
\hline 2008 & 812 & 33 & 542 & 8.368 & 410 & 943 & 11.108 & 1,7 \\
\hline 2009 & 436 & 41 & 647 & 8.375 & 285 & 805 & 10.588 & 1,9 \\
\hline
\end{tabular}

**IRGs: Industrial rubber goods

***GRGs: General rubber goods

Mulai tahun 2000, gambaran ekspor sudah termasuk re-ekspor

Start from 2000, export profile included re-export 
ekspor dan elastisitas permintaan. Namun dalam beberapa tahun terakhir, model populer yang banyak diterapkan adalah model koreksi kesalahan atau ECM (Error Correction Model). Berbagai studi empiris telah dilakukan untuk mengestimasi elastisitas pendapatan dan harga dalam kerangka kointegrasi dengan menggunakan model ECM (Arize, 2001; Behar dan Edwards, 2004; Afzal, 2004; Mencet et al., 2006). Model ECM digunakan karena menyediakan analisis persamaan tunggal dengan menggunakan data non-stasioner. Apabila mengguna-kan model ECM, maka spesifikasi ECM untuk permintaan ekspor sarung tangan adalah sebagai berikut:

$$
\begin{aligned}
\Delta \ln Q_{\mathrm{STt}}= & \alpha+\sum \beta_{1} \Delta \ln Q_{\mathrm{ST}}+\sum \beta_{2} \Delta \ln \mathrm{P}_{\mathrm{ST} \mathrm{t}}+ \\
& \sum \beta_{3} \Delta \ln \mathrm{Y}_{\mathrm{t}}+\sum \beta_{4} \Delta \ln \mathrm{P}_{\mathrm{KSt}}+\beta_{5} \mathrm{ECM}_{\mathrm{t}-1} \\
& +\varepsilon_{\mathrm{t}} \ldots \ldots \ldots \ldots \ldots(2)
\end{aligned}
$$

di mana:

$\mathrm{Q}_{\mathrm{ST}}$ : jumlah ekspor sarung tangan,

$\mathrm{P}_{\mathrm{ST}}$ : harga ekspor sarung tangan,

$\mathrm{Y}$ : pendapatan dunia,

$\mathrm{P}_{\mathrm{KS}}$ : harga substitusi (harga karet sintetis)

Dalam jangka pendek, kelam-banan (lag) sangat berpengaruh terhadap jumlah ekspor, sehingga model ECM untuk permintaan ekspor sarung tangan adalah sebagai berikut:

$$
\begin{aligned}
\Delta \ln Q_{\mathrm{ST} \mathrm{t}}= & \mathrm{c}+\sum \beta_{1} \Delta \ln \mathrm{Q}_{\mathrm{ST} \mathrm{t}-1}+\sum \beta_{2} \Delta \ln \mathrm{P}_{\mathrm{ST} \mathrm{t}}+ \\
& \sum \beta_{3} \Delta \ln \mathrm{Y}_{\mathrm{t}-1}+\sum \beta_{4} \Delta \ln \mathrm{P}_{\mathrm{KSt}}+\beta_{5} \\
& \mathrm{ECM}_{\mathrm{t}-1} \\
& +\varepsilon_{\mathrm{t}} \ldots \ldots \ldots \ldots \ldots . . .(3)
\end{aligned}
$$

\section{HASIL DAN PEMBAHASAN}

\section{Estimasi Permintaan Ekspor Sarung Tangan Medis/Bedah}

Tabel 4 menguraikan secara rinci hasil uji unit root ADF dan PP yang dilakukan untuk produk sarung tangan. Hasil pengujian menunjukkan bahwa semua variabel stasioner di tingkat first difference. Seperti yang dilihat pada Tabel 4, untuk data di tingkat level, tidak ada satupun dari hasil tes yang menolak hipotesis Ho, baik pada tingkat signifikansi 5\% ataupun tingkat signifikansi $10 \%$. Ini berarti bahwa, data non-stasioner pada tingkat level. Namun, di tingkat first difference, hasil tes ADF dan PP secara nyata menolak hipotesis Ho pada tingkat signifikansi $1 \%$. Oleh karena itu berdasarkan uji ADF dan PP, disimpulkan bahwa semua variabel yang digunakan dalam penelitian ini adalah stasioner pada tingkat first difference, atau I (1).

Langkah berikutnya adalah untuk menentukan apakah kombinasi dari variabel-variabel tersebut terkointegrasi dalam jangka panjang, dengan menganalisisnya dengan uji kointegrasi Johansen (Johansen, 1988; Johansen dan Juselius, 1990). Tabel 5. menunjukkan hasil kointegrasi untuk uji Eigen Value ( $\lambda$ Max) dan uji Trace ( $\lambda$ Trace test). Kedua uji statistik memperlihatkan bahwa terdapat hubungan jangka panjang yang stabil antara permintaan ekspor sarung tangan terhadap harga ekspor, pendapatan dan harga substitusi. Seperti yang ditunjukkan pada Tabel 5, bahwa hipotesis Ho yang menyatakan tidak ada kointegrasi $(\mathrm{r}=0)$ dari tes trace dan tes Eigen Value berhasil ditolak secara tegas untuk fungsi permintaan ekspor sarung tangan, yang artinya bahwa setidaknya ada satu vektor kointegrasi yang terdapat pada fungsi permintaan ekspor sarung tangan tersebut.

Dari hasil uji kointegrasi, diketahui bahwa semua variabel permintaan ekspor terkointegrasi. Hal ini memungkinkan untuk dilaksanakannya uji ECM. Error Correction Model (ECM) digunakan untuk memperkirakan fungsi permintaan. Hasil estimasi ECM dari fungsi permintaan pada Tabel 6 . Dalam analisis fungsi permintaan, dianalisis estimasi elastisitas untuk harga ekspor sarung tangan, pendapatan, dan harga substitusi. Karena semua persamaan permintaan diperkirakan dalam bentuk logaritma natural (ln), sehingga koefisien estimasi untuk setiap variabel merupakan estimasi elastisitas variabel tersebut

Hasil estimasi persamaan sarung tangan menunjukkan bahwa semua variabel yang diestimasi koefisiennya menunjukkan tanda seperti yang diharapkan, namun hanya dua variabel yang signifikan secara statistik pada tingkat kepercayaan $1 \%$. Nilai elastisitas harga ekspor sarung tangan sebesar -1,14 dan signifikan pada tingkat kepercayaan $1 \%$. Hubungan ini sesuai dengan hukum permintaan dimana 
Tabel 3. Nilai ekspor produk lateks Malaysia, 2007

Table 3. Export value of Malaysian latex products, 2007

\begin{tabular}{|c|c|}
\hline $\begin{array}{l}\text { Jenis produk } \\
\text { Type of Products }\end{array}$ & $\begin{array}{l}\text { Nilai ekspor } \\
\text { (Juta RM) } \\
\text { Export value } \\
\text { (Million RM) }\end{array}$ \\
\hline $\begin{array}{l}\text { 1. Jenis sarung tangan non medis/bedah (Gloves, other than surgical } \\
\text { gloves) }\end{array}$ & 5.095 .239 \\
\hline 2. Sarung tangan medis/bedah (Surgical gloves) & 780.413 \\
\hline 3. Kateter (Catheters) & 670.015 \\
\hline 4. Benang karet (Latex threads) & 720.863 \\
\hline $\begin{array}{l}\text { 5. Kabel dan bahan anti penghantar listrik (Wire, cable and other } \\
\text { electrical conductors) }\end{array}$ & 103.044 \\
\hline 6. Pipa dan tube (Piping and tubing) & 307.598 \\
\hline 7. Kondom (Sheath contraceptives) & 151.713 \\
\hline 8. Sabuk (Belting) & 62.150 \\
\hline 9. Balon (Balloons) & 38.887 \\
\hline $\begin{array}{l}\text { 10. Karet non seluler untuk vulkanisir ban sistem dingin } \\
\text { (Precured tread of non-cellular rubber) }\end{array}$ & 19.172 \\
\hline $\begin{array}{l}\text { 11. Karet seluler yang dilapisi kain tekstil (Cellular rubber lined with } \\
\text { textile fabric on one side) }\end{array}$ & 13.399 \\
\hline 12. Sarung jari (Finger stall) & 8.672 \\
\hline 13. Dot dan empeng (Teats and soothers) & 17.360 \\
\hline $\begin{array}{l}\text { 14. Segel pipa dari dari karet vulkanisasi tidak dikeraskan (Pipe seal } \\
\text { rings of unhardened vulcanized rubber) }\end{array}$ & 1.528 \\
\hline
\end{tabular}

Sumber: Departemen Statistik Malaysia, 2008

Source: Department of Statistics, Malaysia, 2008

permintaan ekspor sarung tangan akan menurun sebesar $1,14 \%$ apabila harga ekspornya meningkat $1 \%$. Dengan nilai elastisitas yang lebih dari satu, maka kebijakan dalam perubahan harga ekspor sangat mempengaruhi jumlah ekspor yang diminta.

Dalam jangka pendek, kelambanan (lag) sangat berpengaruh terhadap jumlah ekspor. Koefisien jumlah permintaan ekspor sarung tangan satu triwulan sebelumnya memberi-kan pengaruh yang signifikan terhadap permintaan ekspornya pada triwulan sekarang sebesar 0,22. Dengan demikian, jika permintaan ekspor sarung tangan pada satu triwulan yang lalu meningkat sebesar 1\%, maka permintaan ekspor sarung tangan akan meningkat sebesar $0,22 \%$ dibandingkan periode sebelumnya. Hal ini menjadi realistis dalam arti bahwa ekspor membutuhkan penyesuaian terhadap perbedaan yang timbul antara jumlah permintaan pada triwulan sekarang dengan triwulan sebelum-nya. Dengan begitu, ekspor melakukan penyesuaian secara parsial terhadap perbedaan tersebut.
Elastisitas pendapatan negara-negara pengimpor terhadap ekspor sarung tangan, nilainya sebesar 0,51 dan tidak signifikan secara statistik, menunjuk-kan bahwa perubahan pendapatan tidak mempunyai pengaruh yang signifikan terhadap permintaan ekspor sarung tangan.

Dengan nilai elastisitas 0,06 yang tidak signifikan secara statistik, juga menyebabkan perubahan harga karet sintetis tidak memberikan pengaruh yang nyata terhadap jumlah ekspor sarung tangan. Hal ini disebabkan permintaan sarung tangan karet sintetis juga masih kecil, karena saat ini hanya diperuntukkan bagi konsumen yang alergi terhadap sarung tangan karet alam.

\section{Kebijakan-Kebijakan terhadap Ekspor Barang Jadi Karet di Malaysia}

Untuk mendorong pertumbuhan ekspor industri barang jadi karet di Malaysia, beberapa kebijakan telah dilakukan. Sejak periode kelima Malaysia 
Tabel 4. Hasil uji unit root Augmented Dickey Fuller (ADF) dan Philip Peron (PP) terhadap variable-variabel di tingkat level dan first difference

Table 4. Results of unit root test of towards the Augmented Dickey Fuller test (ADF) and the Philip Peron test (PP) stationarity (variables in levels and first differences)

\begin{tabular}{|c|c|c|c|c|c|c|c|c|}
\hline \multirow{2}{*}{$\begin{array}{l}\text { Komoditas } \\
\text { Commodity }\end{array}$} & \multicolumn{4}{|c|}{ Level } & \multicolumn{4}{|c|}{ First difference } \\
\hline & $\mathrm{k}$ & t-stat & prob* & Ho & $\mathrm{k}$ & t-stat & prob* & Ho \\
\hline \multicolumn{9}{|c|}{$\begin{array}{l}\text { Tes Augmented Dickey Fuller (ADF) } \\
\text { The Augmented Dickey Fuller test }(A D F)^{* *}\end{array}$} \\
\hline $\begin{array}{l}\text { Harga ekspor } \\
\text { Export price }\end{array}$ & 1 & $-2,58$ & 0,11 & $\begin{array}{l}\text { terima Ho } \\
\text { accept Ho }\end{array}$ & 1 & $-6,11$ & 0,00 & $\begin{array}{l}\text { tolak Ho } \\
\text { reject Ho }\end{array}$ \\
\hline $\begin{array}{l}\text { Pendapatan } \\
\text { World income }\end{array}$ & 1 & 0,71 & 0,99 & $\begin{array}{l}\text { terima Ho } \\
\text { accept Ho }\end{array}$ & 1 & $-6,35$ & 0,00 & $\begin{array}{l}\text { tolak Ho } \\
\text { reject Ho }\end{array}$ \\
\hline $\begin{array}{l}\text { Kuantitas } \\
\text { Export quantity }\end{array}$ & 1 & $-2,22$ & 0,20 & $\begin{array}{l}\text { terima Ho } \\
\text { accept Ho }\end{array}$ & 1 & $-5,65$ & 0,00 & $\begin{array}{l}\text { tolak Ho } \\
\text { reject Ho }\end{array}$ \\
\hline $\begin{array}{l}\text { Harga substitusi } \\
\text { Price substitute }\end{array}$ & 1 & $-1,66$ & 0,44 & $\begin{array}{l}\text { terima Ho } \\
\text { accept Ho }\end{array}$ & 1 & $-5,37$ & 0,00 & $\begin{array}{l}\text { tolak Ho } \\
\text { reject Ho }\end{array}$ \\
\hline \multicolumn{9}{|c|}{$\begin{array}{l}\text { Tes Philip Peron (PP) })^{* * *} \\
\text { The Philip Peron test }(P P)^{* * *}\end{array}$} \\
\hline $\begin{array}{l}\text { Harga ekspor } \\
\text { Export price }\end{array}$ & 5 & $-2,59$ & 0,10 & $\begin{array}{l}\text { terima Ho } \\
\text { accept Ho }\end{array}$ & 1 & $-6,13$ & 0,00 & $\begin{array}{l}\text { tolak Ho } \\
\text { reject Ho }\end{array}$ \\
\hline $\begin{array}{l}\text { Pendapatan } \\
\text { World income }\end{array}$ & 1 & 0,84 & 0,99 & $\begin{array}{l}\text { terima Ho } \\
\text { accept Ho }\end{array}$ & 1 & $-6,35$ & 0,00 & $\begin{array}{l}\text { tolak Ho } \\
\text { reject Ho }\end{array}$ \\
\hline $\begin{array}{l}\text { Kuantitas } \\
\text { Export quantity }\end{array}$ & 1 & $-2,35$ & 0,16 & $\begin{array}{l}\text { terima Ho } \\
\text { accept Ho }\end{array}$ & 1 & $-5,65$ & 0,00 & $\begin{array}{l}\text { tolak } \mathrm{Ho} \\
\text { reject Ho }\end{array}$ \\
\hline $\begin{array}{l}\text { Harga substitusi } \\
\text { Price substitute }\end{array}$ & 1 & $-1,81$ & 0,37 & $\begin{array}{l}\text { terima Ho } \\
\text { accept Ho }\end{array}$ & 1 & $-5,36$ & 0,00 & $\begin{array}{l}\text { tolak Ho } \\
\text { reject Ho }\end{array}$ \\
\hline $\begin{aligned} * & \text { MacKinnon (1996) nil } \\
* *: & \text { maksimum lag, } \\
* * * & \text { (maximumlag, } \\
& \text { bandwidth fixe } \\
& \text { (bandwidth, fixe }\end{aligned}$ & & $\begin{array}{l}\text { kaike I } \\
\text { enfrorn } \\
\text { in Barle } \\
\text { Thernel }\end{array}$ & $\begin{array}{l}\text { lues) } \\
\text { ation Cr } \\
\text { Criterio } \\
\text { nel }\end{array}$ & $\left(\begin{array}{ll}(\mathrm{AIC}) \\
)\end{array}\right.$ & & & & \\
\hline
\end{tabular}

Plan, pengembangan industri barang jadi karet berpedoman pada Master Plan Industri atau Industrial Master Plan (IMP) yang dikeluarkan oleh pemerintah yang telah memberikan dorongan lebih besar terhadap pertumbuhan sektor manufaktur karet di Malaysia (Malaysian Rubber Board, 2008). Produk industri hilir karet tumbuh secara signifikan selama Master Plan Industri yang kedua (IMP2). Selanjutnya, Master Plan Industri Ketiga (IMP3) diimplementasikan untuk periode tahun 2006 - 2020 untuk menunjang kesinambungan pembangunan industri tersebut (Ministry of International Trade and Industry Malaysia, 2006). Saat ini merupakan periode ketiga dari Master Plan Industri (IMP3) dimana Malaysia mentargetkan pendapatan ekspor barang jadi karet menjadi RM 23,6 miliar pada tahun 2020. Beberapa strategi yang bisa diterapkan untuk mencapai target industri tersebut antara lain:

(1). Meningkatkan posisi Malaysia sebagai produsen utama produk lateks di dunia. Berbagai upaya telah dilakukan untuk memperkenalkan merek produk dan memperluas pasar ekspor untuk produk lateks. Pemerintah telah mempromosikan Standard Malaysian Glove (SMG) untuk membuat produk sarung tangan 
lateks dan ini lebih diakui dan diterima secara internasional. Perusahaanperusahaan penghasil sarung tangan telah didorong untuk memperoleh sertifikasi Standard Malaysian Glove (SMG) untuk memastikan kualitas dan kehandalan produk yang dihasilkan.

(2). Memperluas pasar ekspor

Hal ini dilakukan melalui kegiatan promosi perdagangan yang dilakukan secara komprehensif dan terkoordinasi antara instansi-instansi peme-rintah terkait, termasuk Malaysia External Trade Development Corporation (MATRADE), The Ministry of Plantation Industries and Commodities (MPIC), Lembaga Getah Malaysia atau Malaysia Rubber Board (MRB) dan Malaysian Rubber Export Promotion Council (MREPC). Selain itu, keterlibatan dalam pameran inter-nasional, baik di Malaysia maupun di luar negeri, telah dilakukan oleh MATRADE. Pasar ekspor yang baru, seperti Amerika Latin, Afrika, Asia Barat dan Asia Tengah, telah memberikan potensi ekspor yang penting bagi industri ini.

(3). Mendorong investasi ke luar negeri.

Salah satu upaya untuk meningkatkan daya saing harga ekspor barang jadi karet adalah menekan biaya produksi. Upaya yang telah dilakukan Pemerintah Malaysia melalui The Malaysian Industrial Development Authority (MIDA) antara lain dengan mempromosikan dan mendukung investasi keluar negeri untuk mendapat-kan bahan baku yang lebih murah. Kerjasama investasi tersebut dilakukan dengan negaranegara ASEAN lainnya, yang memiliki bahan baku karet dan biaya produksi yang lebih rendah, misalnya dengan negara Indonesia.

(4). Diversifikasi produk penelitian dan pengembangan ( $R \& D)$.

Kegiatan penelitian dan pengembangan lebih ditingkatkan untuk memastikan bahwa produk lateks Malaysia memenuhi standar internasional dalam hal kesehatan dan keamanan. Selain itu intensifikasi kegiatan-kegiatan penelitian dan pengembangan juga difokuskan pada peningkatan teknologi manufaktur dan nilai tambah produkproduk yang lebih tinggi (Ministry of International Trade and Industry, 2006).

\section{KESIMPULAN}

Hasil analisis menunjukkan bahwa nilai elastisitas harga ekspor sarung tangan sebesar $-1,14$ dan signifikan pada tingkat kepercayaan $1 \%$. Dengan nilai elastisitas yang lebih dari satu, maka kebijakan dalam perubahan harga ekspor sangat mempengaruhi jumlah ekspor yang diminta. Sementara, nilai elastisitas pendapatan negara-negara pengimpor, dan elastisitas karet sintetis tidak signifikan secara statistik dan masing-masing nilainya sebesar 0,51 dan 0,06, menunjukkan bahwa perubahan pada kedua variabel tersebut tidak mempunyai pengaruh yang signifikan terhadap permintaan ekspor sarung tangan. Faktor-faktor tersebut dirumuskan ke dalam bentuk model:

$$
\begin{aligned}
\Delta \ln \mathrm{Q}_{\mathrm{STt}}= & 0.002+0.18 \Delta \ln \mathrm{Q}_{\mathrm{STt}-1}-1.14 \Delta \ln \mathrm{P}_{\mathrm{ST}} \\
& +0.51 \Delta \ln \mathrm{t}_{\mathrm{t}-1}+0.06 \Delta \ln \mathrm{P}_{\mathrm{KS}}- \\
& 0.12 \mathrm{ECM}_{\mathrm{t}-1} .
\end{aligned}
$$

Dengan besarnya pengaruh perubahan harga ekspor sarung tangan, maka peningkatan daya saing harga merupakan strategi yang tepat jika Malaysia ingin meningkatkan ekspor sarung tangan karet. Hal ini salah satunya dapat dicapai dengan upaya mengurangi biaya produksi sarung tangan, antara lain mengurangi biaya produksi bahan baku karet. Upaya tersebut sejalan dengan kebijakan pemerintah Malaysia yang tertuang pada the Third Industrial Malaysia Plan (IMP3), melalui upaya-upaya yang dilakukan oleh the Malaysian Industrial Development Authority (MIDA) dengan mendukung investasi keluar negeri untuk mendapatkan bahan baku karet yang lebih murah.

\section{DAFTAR PUSTAKA}

Arize. 2001. The supply and demand for imports and exports in a simultaneous model. Applied Economics, 19, 12331247.

Afzal, M. 2004. Estimating long-run trade elasticities in Pakistan: A Cointegration approach. The Pakistan Development Review. 43:4 Part II, 757-770. 
Behar, A. and L. Edwards. 2004. Estimating Elasticities of Demand and Supply for South African Manufacturing Export Using A Vector Error Correction Model. The Centre for Stay of African Economic Paper Series. Cape town: The Berkeley Electronic Press (Bepress).

Johansen, S. 1988. Statistical analysis of cointegration vectors. J. Economic Dynamics and Control, 12, 231-254.

Johansen, S. and K. Juselius. 1990. Maximum likelihood estimation and inference on co-integration with applications to the demand for money. Oxford Bull. of Economics and Statistics, 52(2), 169-210.

Lembaga Getah Malaysia. 2010. Malaysia Rubber Statistics. www.lgm.gov.my., diakses 12 April 2011.

Mackinnon, J.G., A.H. Alfred and L. Michelis. 1999. Numerical distribution functions of likelihood ratio test for cointegration. J. Applied Econometrics, 5, 563-577.

Malaysian Industrial Development Authority. 2008. Industries in Malaysia. Rubber Based Industry. www.mida.gov. my., diakses 2 Februari 2008.
Malaysian Rubber Board. 2008. The Malaysian Natural Rubber Industry. www.lgm.gov.my. diakses 7 Oktober 2008.

Mencet, M. Nisa, M.F. Ziya, and C. Sayin. 2006. In Cointegration Analysis of Wine Export Prices for France, Greece and Turkey. European Association of Agricultural Economics in its Series 98 ${ }^{\text {th }}$ Seminar, June 29-July 2, 2006. Chania; Crete: Greece, 2006.

Ministry of International Trade and Industry Malaysia. 2006. Third Industrial Master Plan 2006-2020. Malaysia Towards Global Competitiveness. Kuala Lumpur: Percetakan Nasional Malaysia Berhad.

Susanto. 2002. Measuring the Degree of Market Power in the Export Demand for Soybean Complex. Unpublished doctoral dissertation, Louisiana State University, USA. 